This is an Open Access article licensed under the terms of the Creative Commons AttributionNonCommercial 3.0 Unported license (CC BY-NC) (www.karger.com/OA-license), applicable to

\title{
Nexrutine Inhibits Cancer Cell Growth as a Consequence of Mitochondrial Damage and Mitophagy
}

\author{
Xiang $W^{a, b}$ Shao-ming Zhou ${ }^{b}$ Yi-Ling Ding ${ }^{a} \quad$ Ying-ping Gong ${ }^{b}$ Weiqi Zeng ${ }^{c}$ \\ Yi Cui ${ }^{b}$ \\ aDepartment of Obstetrics and Gynecology, Second Xiangya Hospital, Central South University, \\ Changsha, Hunan, China, ${ }^{\circ} T$ The Maternal and Child Heath Hospital of Hunan Province, Changsha, \\ Hunan, China, 'Department of Dermatology, Xiangya Hospital, Central South University, Changsha, \\ Hunan, China
}

\author{
Key Words \\ Nexrutine • Autophagy • Mitophagy • p21 • p27
}

\begin{abstract}
Background/Aims: Nexrutine is an herbal extract of Phellodendron amurense and has been used as nutrient supplement in China as well as America. Potential protection effect of Nexrutine has been reported. Methods: To investigate the mechanism of Nexrutine, we used the HeLa, U2OS and HCT116 as a model. Based on the acidification of cell culture media, we examined the lactate, mitochondria damage as well as mitophagy status by corresponding assay. Results: Our data suggest that Nexrutine alters the cellular glucose metabolism to promote lactate production. This effect is caused by mitochondrial damage, not an alteration to lactate dehydrogenase activity. As a result of the mitochondrial damage, cell proliferation was inhibited and was associated with an elevation in p21/p27 proteins, which are both important cell cycle inhibitors. As another consequence of the mitochondrial damage, mitophagy was highly activated in Nexrutine-treated cells in a dose-dependent manner. When the autophagy pathway was blocked by siRNAs against BECN1 or ATG7, the growth inhibition caused by Nexrutine was reversed. Conclusion: Our study revealed that autophagy plays an important role in the inhibition of cancer cell proliferation by Nexrutine.
\end{abstract}




\section{Cellular Physiology Cell Physiol Biochem 2015;36:763-772

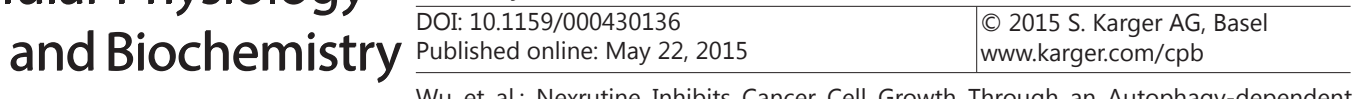 \\ Wu et al.: Nexrutine Inhibits Cancer Cell Growth Through an Autophagy-dependent Mechanism}

\section{Introduction}

Nexrutine (Nex) is a fractionated extract of a tree used in traditional Chinese medicine, Phellodendron amurense, also known as the Amur cork tree. Phellodendron extracts have been used traditionally in Chinese medicine for hundreds of years as antidiarrheal, astringent, and anti-inflammatory agents. Nexrutine is considered a natural treatment for pain and inflammation in the U.S.A. The first research on Nexrutine was published in 2004. Cyclooxygenase 2 (COX-2) was identified as a downstream effector of Nexrutine [1]. COX2 is responsible for the formation of important biological mediators called prostanoids, including prostaglandins, prostacyclin and thromboxane. The pharmacological inhibition of COX-2 can provide relief from the symptoms of inflammation and pain and has been reported to inhibit the proliferation of prostate cancer cells [2]. One of the components of Nex is berberine, which has been extensively investigated in multiple clinical trials for the treatment of different cancer types, including hepatocarcinoma, glioma and prostate cancer, and has been shown to target cancer cells without being cytotoxic to normal cells [3-5]. One study of Nex in prostate cancer cells showed that the Akt- and CREB- pathways might be involved in the action of Nex [6].

Mitochondria are important organelles for energy production because they perform the oxygen consumption-driven synthesis of adenosine triphosphate (ATP) (via oxidative phosphorylation, OXPHOS) [7]. However, as a side product of normal respiration, mitochondria produce reactive oxygen species (ROS) that must be detoxified. An impairment of the ROS balance is related to cell growth inhibition and/or cell death. [8-10] High levels of ROS can oxidize cell constituents, such as lipids, proteins and DNA, and can thus disrupt the integrity of cells. An acute ROS signal leads to cell apoptosis [11]. Various defense mechanisms have been developed to protect cells against oxidative stress, such as the upregulation of antioxidants, removal of specific proteins by the ubiquitin-proteasome system and removal of damaged proteins and organelles by autophagy. ROS induces not only cell growth inhibition but also autophagy in a variety of mammalian cells. However, the relationship between these processes is not yet clear. Accumulating data have shown that they are inseparable and that autophagy might mediate the cell growth inhibition caused by ROS [12-14].

Autophagy is a major pathway for the delivery of proteins and organelles to lysosomes in mammals and to vacuoles in yeast, where they are degraded and their components are recycled [15]. The role for autophagy in the response of the cell to ROS is supported by the fact that oxidized proteins accumulate as cells age under normal growth conditions [16]. Mitophagy, the selective degradation of mitochondria, can be induced by several stimuli and has been proposed to decrease the potential oxidative damage caused by defective mitochondria [17]. Essentially, autophagy is thought to be a pro-survival process at its beginning stage. When the survival mechanisms of autophagy fail, death programs are activated in response to oxidative stress. In recent years, it has become accepted that autophagy, in addition to its role in cell survival, can lead to cell growth inhibition and cell death [18-20].

Osteosarcoma, the most common primary solid malignancy of bone, is defined by the presence of malignant mesenchymal cells that produce osteoid and/or immature bone. For osteosarcoma, local therapy alone is insufficient because $80-90 \%$ of all patients with seemingly localized disease develop metastases, primarily in the lungs, and die if chemotherapy is not included as part of a multidisciplinary treatment [21]. Currently, doxorubicin [22], cisplatin [23], high-dose methotrexate with leukovorin-rescue [24] and ifosfamide [25] are considered the most active agents against osteosarcoma.

Our study investigated the cellular effect of Nex and found that Nex can potently induce mitochondrial damage, autophagy and cell growth inhibition in multiple types of cancer cells. Considering that Nexrutine has been used in ongoing phase II clinical trials (http:// clinicaltrials.gov/show/NCT01705652), this study provides valuable information regarding the mechanism of action of Nexrutine in cancer cells. 


\section{Cellular Physiology Cell Physiol Biochem 2015;36:763-772 \\ \begin{tabular}{ll|l}
\hline DOI: 10.1159/000430136 & $\begin{array}{l}\text { C 2015 S. Karger AG, Basel } \\
\text { www.karger.com/cpb }\end{array}$ \\
\hline
\end{tabular} \\ Wu et al.: Nexrutine Inhibits Cancer Cell Growth Through an Autophagy-dependent Mechanism}

\section{Materials and Methods}

\section{Reagents}

Nexrutine was obtained from SLANOVA LLC (Novato, CA) and prepared in dimethyl sulfoxide (DMSO) at $10 \mathrm{mg} / \mathrm{ml}$. All cell culture media, Lipofectamine 2000, Mito-Tracker ${ }^{\circledR}$ dye, G418 and fluorescence conjugated secondary antibodies were purchased from Invitrogen.

\section{Cell culture and $p H$ determination}

U20S, HeLa and HCT116 cells were obtained from the American Type Culture Collection. All cells used in this study were at early passages after receipt or resuscitation (approximately 3 months of noncontinuous culturing). HCT116 p53-/- and HCT116 p21-/- cells were obtained from Dr. Yuan's lab (Harvard School of Public Health). U2OS and all HCT116 cells were maintained in McCoy's medium supplemented with $10 \%$ FBS, $2 \mathrm{mM} / \mathrm{L}$ glutamine, 100 units $/ \mathrm{mL}$ penicillin, and $100 \mu \mathrm{g} / \mathrm{mL}$ streptomycin. HeLa cells were maintained in DMEM medium supplemented with 10\% FBS, 2 mM/L glutamine, 100 units/mL penicillin, and $100 \mu \mathrm{g} / \mathrm{mL}$ streptomycin. Culture media samples were collected at the indicated time points to directly measure their pH with a pH meter (model 340, CORNING, Vernon Hills, IL, USA).

\section{Lactate assay and LDH assay}

U20S, seeded in p35 dishes with $2 \mathrm{ml}$ media, was treated with or without Nex for the indicated times. Subsequently, culture media was harvested for the lactate assay performed with a kit from Eton Bioscience (San Diego, CA, USA). Simply, $20 \mu$ diluted media (1:10 dilution in water) was mixed with $50 \mu$ lactate assay reagent. After 1 hour of incubation at $37^{\circ} \mathrm{C}, 50 \mu \mathrm{l}$ acetic acid was added to the well to stop the reaction. The reactions were performed in 96-well plates and were read with a microplate reader. The LDH assay was performed with a kit from Bioassay (Hayward, CA, USA). After removing the medium from the well, approximately $1 \times 10^{6}$ cells were washed once with PBS and were then de-attached using a rubber scraper. After centrifugation at $2000 \mathrm{x}$ g and $4^{\circ} \mathrm{C}$, the cells were lysed in $200 \mu \mathrm{l}$ lysis buffer. Then, $10 \mu \mathrm{l}$ samples were mixed with $14 \mu \mathrm{l}$ MTT solution, $8 \mu \mathrm{l}$ NAD solution and $170 \mu \mathrm{l}$ substrate buffer. The $\mathrm{OD}_{565 \mathrm{~nm}}$ values of the reaction mixtures were determined before and after incubation at $30^{\circ} \mathrm{C}$ for $25 \mathrm{~min}$. LDH activity was then calculated using the formula indicated in the protocol of the LDH assay kit.

Growth curve and trypan blue assay

U2OS cells were seeded in 96-well plates at 1000 cells/well. The cells were counted using a regular hemocytometer plate. HCT116 cells were seeded in 6 -well plates at $1 \times 10^{5}$ cells/well. The WT, p53-/- and p21-/- HCT116 cells were incubated with or without Nex for 5 days and then examined by trypan blue assay. The surviving cells were counted using a TC20 automated cell counter (Bio-Rad).

\section{Mitochondria tracking and immunocytofluorescence imaging}

U2OS cells were cultured on poly-D-lysine-coated cover slips in McCoy's medium overnight and treated with or without Nex. Thirty minutes before harvesting the cells, Mito-Tracker dye was added to a final concentration of $200 \mathrm{nM} / \mathrm{L}$. The cells were fixed, permeabilized, and incubated with p21 (Abcam), ki67 (Santa Cruz Biotechnology) or beta-actin (Sigma) antibodies and a fluorescein isothiocyanate (FITC)conjugated secondary antibody. Nuclei were counterstained with 4,6-diamidino-2-phenylindole (DAPI). Images were captured at 40× magnification using a Nikon TE-2000U microscope.

Virus production and infection, and siRNA construction

pBabe-BCL2 was purchased from Addgene (www.addgene.org) [26]. 293FT cells were used to package viruses following using a previously published protocol [26]. Simply, pBabe-BCL2 was co-transfected with VSVG and GAG-pol at a 1:1:1 ratio. Seventy-two hours after transfection, the virus soup was collected by centrifugation at $1000 \mathrm{x} g$ for $5 \mathrm{~min}$. For each infection, U20S cells in a p35 dish were incubated with $1 \mathrm{ml}$ virus soup plus Polybrene at a final concentration of $1 \mathrm{ug} / \mathrm{ml}$. Fresh medium was added after 2 hours. After 48 hours, infected cells were selected by adding puromycin $(2 \mu \mathrm{g} / \mathrm{ml})$ to the medium and incubating the cells for another 48 hours. The surviving cells were subjected to western blot to confirm BCL2 expression. siRNA against ATG7 (sense, 5'-UCAAUUUUCACUUUGAUUCUG-3'; antisense, 5'-GAAUCAAAGUGAAAAUUGAGU-3') and BECN1 (sense, 5'-UUAAAUUCACUGUAUUCUCUC-3'; antisense, 5'-GAGAAUACAGUGAAUUUAAAC-3') 


\section{Cellular Physiology Cell Physiol Biochem 2015;36:763-772 \\ \begin{tabular}{ll|l} 
and Biochemistry & $\begin{array}{l}\text { DOI: 10.1159/000430136 } \\
\text { Published online: May 22, } 2015\end{array}$ & $\begin{array}{l}\text { C 2015 S. Karger AG, Basel } \\
\text { www.karger.com/cpb }\end{array}$ \\
\cline { 2 - 3 } Wu et 2 . Nexrutine Inhibits
\end{tabular} Mechanism}

were predesigned and synthesized by Sigma.

\section{Statistical analysis and software}

All experiments were repeated three times. For each histogram, the average values and error bars were calculated from three independent experiments. GraphPad Prism 5 software was used to analyze the data and create the histograms. One-way ANOVA was used to assess the statistical significance of certain data. A double asterisk $\left({ }^{* *}\right)$ indicates $\mathrm{p}<0.01$, and a single asterisk $\left({ }^{*}\right)$ indicates $\mathrm{p}<0.05$.

\section{Results}

Nex treatments increase lactate production without altering LDH activity in cancer cells

When U20S cells were treated with Nex for 48 hours, the color of the culture media changed to yellow. Because phenol red was present in the media, the yellow color of the media indicated that it was acidic (Fig. 1A). We collected media samples and determined their $\mathrm{pH}$. The results showed a dose-dependent effect of Nex on medium $\mathrm{pH}$; higher concentrations of Nex yielded more acidic medium. The acidification of the medium in this case was the result of the cellular response to Nex because Nex is not able to alter medium color when cells are not present (Fig. 1B). Another experiment was performed to verify this conclusion (Fig. 1C): After cells were treated with Nex, the medium was replaced with medium lacking Nex, and the Nex-treated cells were found to acidify the medium lacking Nex (Fig. 1D).

In cell metabolism, lactate is a major source of acid; thus, we measured the relative lactate concentration in the medium. An increase in lactate production in cells treated with a high concentration of Nex was observed (Fig. 1E), which was consistent with the lower pH of the medium in that condition. In glucose metabolism, lactate production is tightly controlled by the lactate dehydrogenase (LDH) enzyme, the key regulator of lactate production [27]. No difference in LDH activity was observed between cells with and without Nex treatment (Fig. $1 \mathrm{~F}$ ), which suggests that enzymes in glucose metabolism other than LDH play an important role in Nex-induced lactate production.

Nex induces severe mitochondrial damage as well as mitophagy independent of BCL2

Mitochondria produce energy by pyruvate consumption, and pyruvate is the homologue of lactate and can be transformed to lactate by LDH under certain conditions, including mitochondrial damage [28]. Mito-Tracker has been used to label mitochondria in living cells. After staining with Mito-Tracker, cells harboring intact mitochondria have long and linearshaped red signals (Fig. 2A upper panel), and cells with damaged mitochondria have red, round dot signals (Fig. 2A lower panel) because of mitochondrial fragmentation. Another sign of mitochondrial damage is the signal intensity of Mito-Tracker; greater mitochondrial damage yields a stronger signal. We treated U20S cells with Nex at the indicated doses, and the Mito-Tracker signal increased in a dose-dependent manner, but the control $\beta$-actin signal did not. Nex treatment at $1 \mu \mathrm{g} / \mathrm{ml}$ for 12 hours was sufficient to induce mitochondrial damage in half of the treated cells (Fig. 2B).

GFP-LC3, the most efficient tool for monitoring autophagy, was transfected into U2OS cells, and the cells were then treated with Nex at different doses for 12 hours (Fig. 2C). Without Nex treatment, GFP-LC3 proteins were distributed sporadically, with no clear aggregates. At $1 \mu \mathrm{g} / \mathrm{ml}$ Nex, certain cells showed mitochondrial damage, and GFP-LC3 aggregates were found in the same region as the damaged mitochondria. This suggests that mitophagy was activated to eliminate the damaged mitochondria. Following treatment with increasing doses of Nex dose, GFP-LC3 accumulation and aggregation with damaged mitochondria increased in a dose-dependent manner (Fig. 2C).

$\mathrm{Bcl}-2$ (B-cell lymphoma 2) is the founding member of the Bcl-2 family of apoptosis regulator proteins encoded by the BCL2 gene. It maintains cell viability by decreasing mitochondrial membrane permeability and blocking cytochrome $c$ release under conditions of mitochondrial damage. We introduced exogenous BCL2 into U2OS cells to block the 


\section{Cellular Physiology Cell Physiol Biochem 2015;36:763-772 \begin{tabular}{ll|l} 
and Biochemistry Published online: May 22, 2015 & $\begin{array}{l}\text { O 2015 S. Karger AG, Basel } \\
\text { www.karger.com/cpb }\end{array}$ \\
\cline { 2 - 3 }
\end{tabular} \\ Wu et al.: Nexrutine Inhibits Cancer Cell Growth Through an Autophagy-dependent Mechanism}

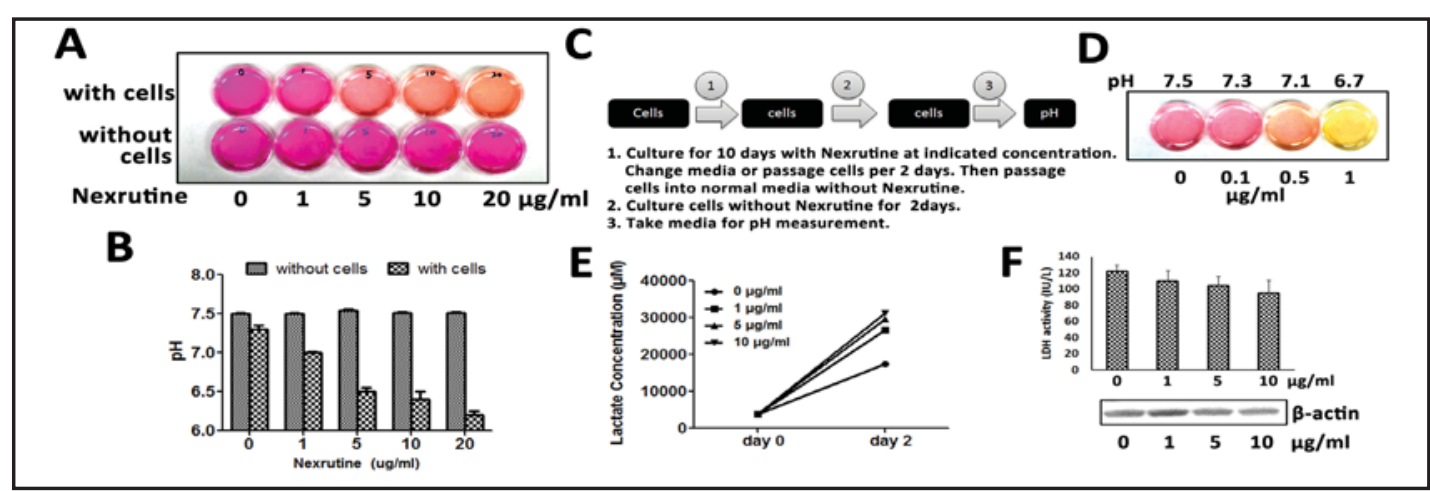

Fig. 1. Nex induces LDH-independent lactate release. (A) U2OS cells were seeded in p35 dishes and treated with Nex at the indicated concentrations for 14 hours. Medium only plus Nex served as the control. (B) Medium $\mathrm{pH}$ was determined with a pH meter. U2OS cells treated with Nex. (C) Photo of medium. (D) Media were collected and subjected to lactate assay (E). (F) After measuring lactate, the cells were harvested and subjected to LDH assay and western blot. $\beta$-actin was used as a control to normalize the samples.

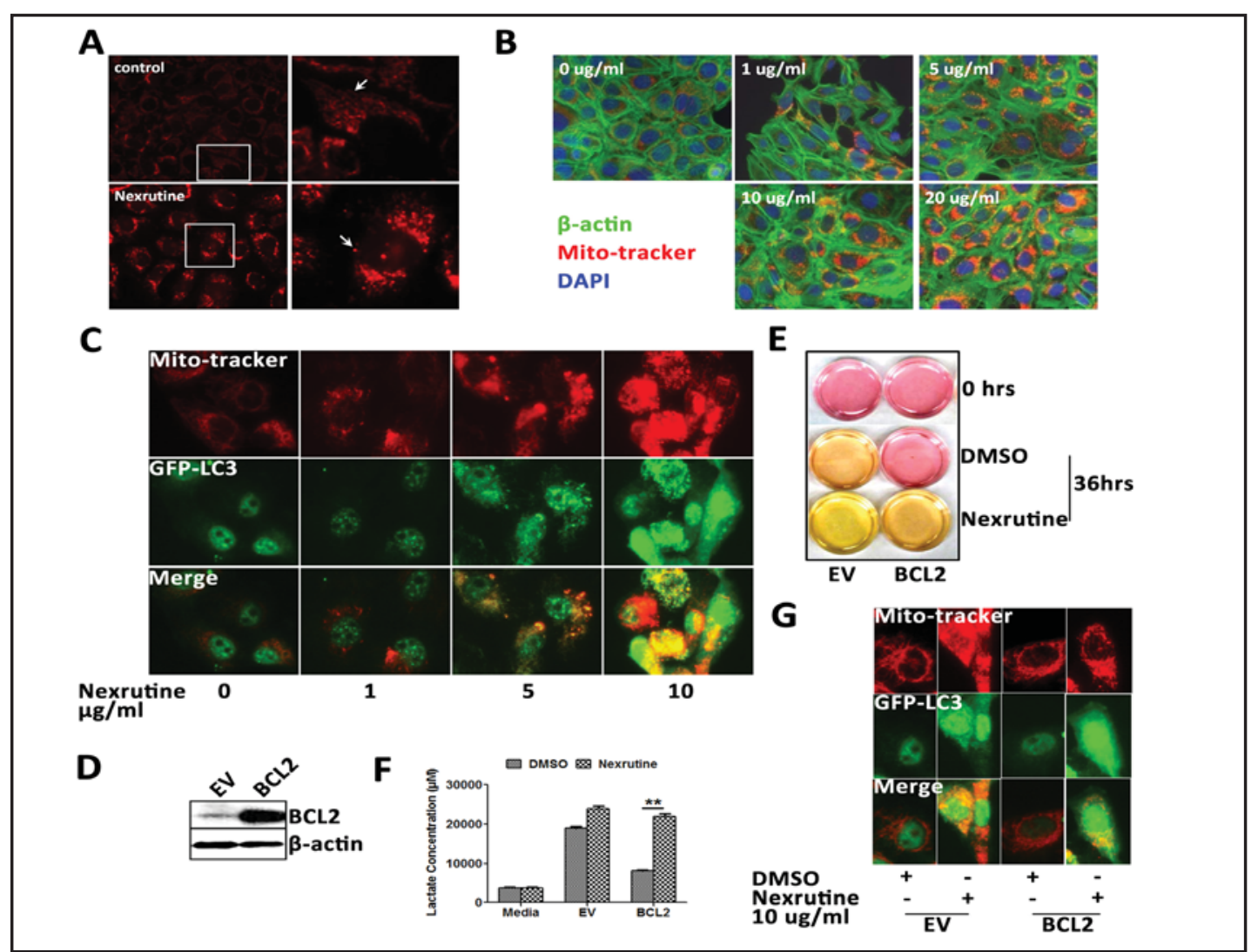

Fig. 2. Nex induces mitochondrial damage without altering membrane permeability. (A) U2OS cells treated with $10 \mu \mathrm{g} / \mathrm{ml}$ Nex for 12 hours. $100 \mu \mathrm{M}$ Mito-Tracker ${ }^{\circledR}$ was added to the media 30 minutes before fixation. (B) Cells were treated with the indicated doses of Nex. After incubation with Mito-Tracker $®$ for 30 minutes, cells were fixed and subjected to immunofluorescence assay. The signals, nuclear (blue)/ $\beta$-actin (green)/mitochondria (red), were observed and captured with a microscope. (C) GFP-LC3 was used to monitor autophagy status. Cells transfected with GFP-LC3 were treated with Nex at the indicated concentrations for 12 hours. Cells were fixed and subjected to immunofluorescence assay. (D) U2OS cells were infected with pBabe empty vector (EV) or pBabe-BCL2 virus and were then selected by puromycin $(2 \mu \mathrm{g} / \mathrm{ml})$ for 2 days. After 3 days of recovery, cells were subjected to western blot. (E) U2OS-EV or -BCL2 stable cell lines were treated with Nex at $1 \mu \mathrm{g} / \mathrm{ml}$ for 36 hours. The initial and final colors of media were captured. (F) Lactate in media was also determined. (G) U2OS-EV or -BCL2 cells under the same treatment with (E) were subjected to immunofluorescence assay. 


\section{Cellular Physiology \\ Cell Physiol Biochem 2015;36:763-772 and Biochemistry \begin{tabular}{|l|l|}
\hline DOI: 10.1159/000430136 & C 2015 S. Karger AG, Basel \\
\hline
\end{tabular} \\ Wu et al.: Nexrutine Inhibits Cancer Cell Growth Through an Autophagy-dependent Mechanism}

Fig. 3. Nex treatment decreases U2OS cell proliferation rate and elevates p21/p27 levels. (A) Growth curve of U20S cells treated with different concentrations of Nex. Cells were seeded in 96-well plates at 1000 cells/well with Nex at the indicated concentrations. Cell numbers were counted on the indicated days. (B) U2OS cells were treated with Nex for 1 week at the indicated concentrations and then harvested and subjected to western blot. Membranes were probed with the indicated antibodies. (C) U2OS cells were treated with Nex for 1 week and then fixed for the immunofluorescence assay. (D) For (C), cells expressing p21 or Ki67 were counted. The total cell number indicated by DAPI was divided by the number of cells expressing p21 or Ki67. At least 200 cells were counted for each sample. (E) U2OS cells were transfected with small siRNA, siNC (non-target control) or sip53. After 24 hours, cells were treated with Nex $(1 \mu \mathrm{g} / \mathrm{ml})$ for 3 days. Then, cells were harvested for western blot.

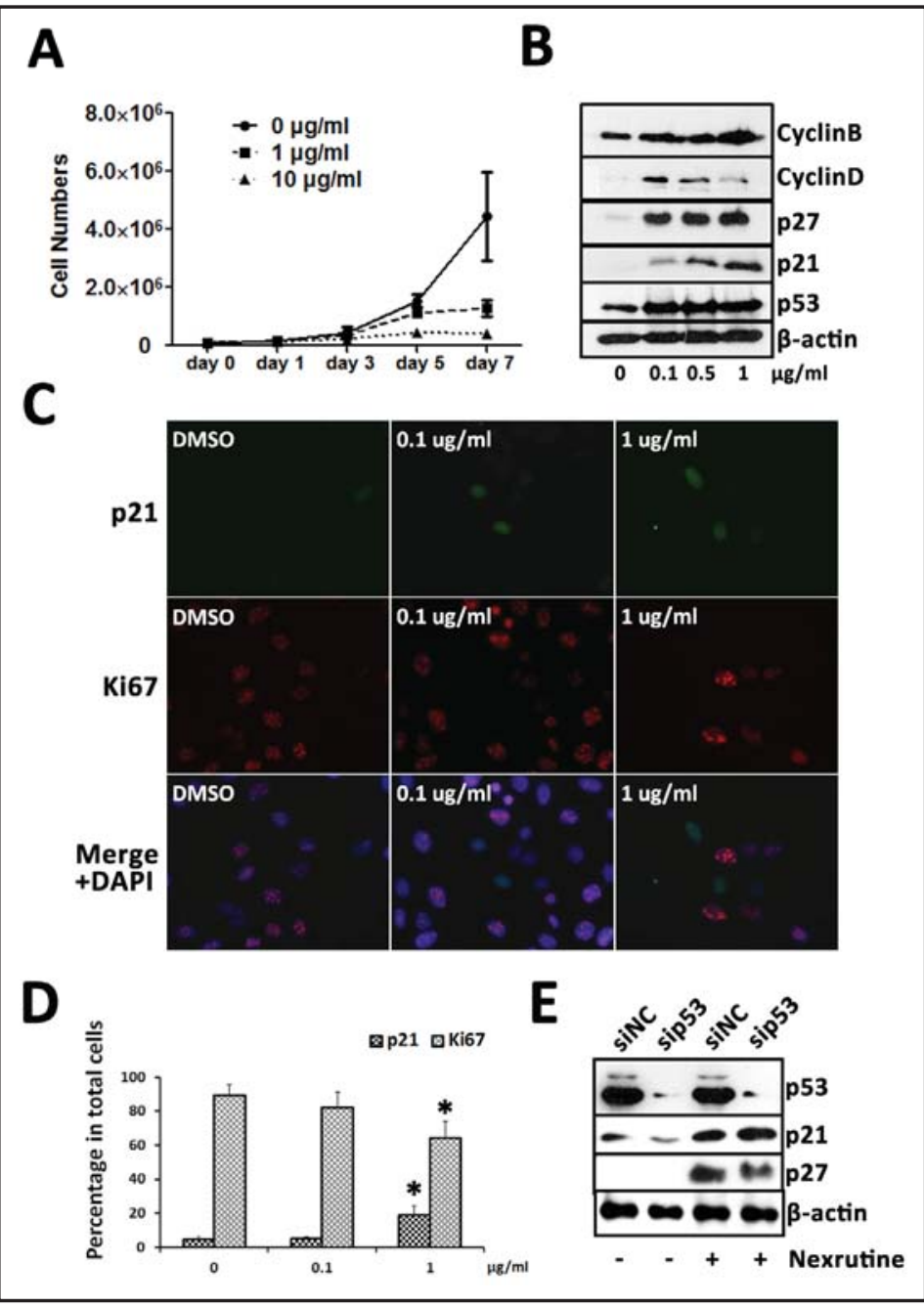

mitochondrial damage caused by Nex. Exogenous BCL2 was highly overexpressed in U2OS cells (Fig. 2D), and it efficiently protected against mitochondrial damage under $\mathrm{H}_{2} \mathrm{O}_{2}$ treatment (data not shown). However, BCL2 was not able to block lactate production under Nex treatment (Fig. 2E, F). We also used GFP-LC3 as a marker of mitophagy under Nex treatment. Consistent with the lactate results, BCL2 was not able to block mitophagy activation or mitochondrial damage (Fig. 2G). This result suggests that Nex-induced lactate production and mitochondrial damage are largely unrelated to the loss of mitochondrial membrane permeability.

Nex inhibits cell growth and induces the expression of cell cycle inhibitors p21 and p27

Inhibition of cell proliferation by Nex has been reported in prostate cancer cells [10]. When we treated U2OS cells and HCT116 cells with Nex at less than $10 \mu \mathrm{g} / \mathrm{ml}$, minimal cell death was detected. However, the growth curve of those cells indicated, surprisingly, that 1 $\mu \mathrm{g} / \mathrm{ml}$ Nex can efficiently inhibit cell growth (Fig. 3A). Thus, Nex has a mechanism other than apoptosis induction to inhibit cancer cell growth.

Cell growth and the cell cycle are tightly controlled by cyclin/Cdk complexes and their inhibitors, p21/p27. In Nex-treated cells, p21/p27 showed significantly dose-dependent increases at the protein level (Fig. 3B). Ki67, which is a proliferation marker, was examined by immunofluorescence and was found to decrease in Nex-treated cells (Fig. 3C, D). This result is consistent with the induction of p21/p27 by Nex, suggesting that Nex is capable of inhibiting cell cycle and growth. 


\section{Cellular Physiology \\ Cell Physiol Biochem 2015;36:763-772 \\ Wu et al:: Nexrutine Inhibits Cancer Cell Growth Through an Autophagy-dependent Mechanism}

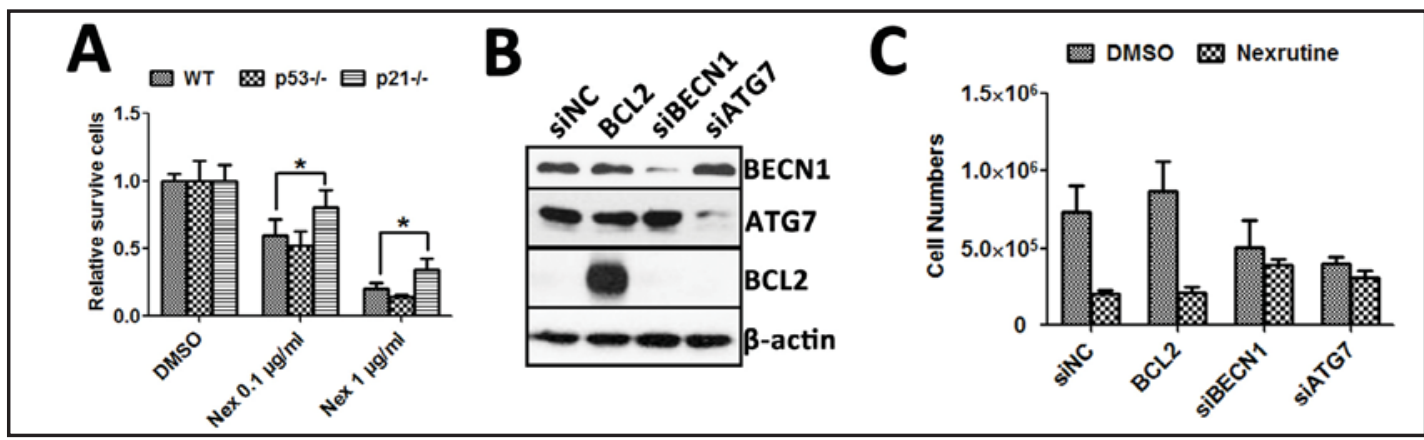

Fig. 4. Inhibition effect of Nex was efficiently recovered by blocking autophagy. (A) HCT116 wild type, p53-/- and p21-/- cells were seeded into 96-well plates at 5000 cells/well. Nex was added to culture media at the indicated concentrations. After 3 days, cells were trypsinized for the trypan blue assay. Cell numbers in the wild type group were set as $100 \%$. (B) Western blots were used to verify BCL2 overexpression and BECN1 and ATG7 depletion in U2OS cells. (C) Indicated U2OS cells were seeded in p35 dishes at $5 \times 10^{5}$ cells/dish with DMSO or Nex $(1 \mu \mathrm{g} / \mathrm{ml})$. After 5 days, cells were trypsinized for the trypan blue assay.

p53 has been identified as the most potent cell cycle inhibitor, and it acts by driving p 21 expression under stress conditions (5). We used siRNA to deplete p53 and then treated cells with Nex, and the induction of p 21 and p 27 by Nex was not altered by p53 depletion (Fig. 3E).

Mitophagy mediated the growth inhibition effect of Nex

HCT116 wild type, p53-/- and p21-/- cells were seeded and treated with Nex for 7 days. The trypan blue assay was used to determine the amount of cellular survival. For each cell type, the cell number of the DMSO group was set as 100\%. The growth rate of the p53-/- cells was similar to that of the DMSO control cells. Thus, p21-/- cells exhibited a slight resistance to Nex treatment (Fig. 4A). Moreover, mitophagy caused by Nex treatment was investigated with siRNA against BECN1 and ATG7, which are both key regulators of autophagy. Western blot was used to verify the depletion efficiency of the siRNAs against BECN1 and ATG7 and to verify BCL2 expression. Both BECN1 and ATG7 were depleted by over $70 \%$ by their respective siRNAs (Fig. 4B). Cell growth inhibition caused by Nex was significantly ameliorated by both BECN1 and ATG7 depletion, but BCL2 depletion did not result in the same effect (Fig. 4C).

\section{Discussion}

Nex was the first anti-inflammatory nutrient supplement and has been used since 1999 . Accumulating studies have shown that when treated with Nex, prostate cancer cells undergo anti-cancer effects that are mediated by AKT, CREB and COX-2 $[2,6]$. Nex-induced apoptosis has been investigated in multiple cancer cell types, such as prostate cancer [2], melanoma [29] and breast cancer cells [30]. When we treated U2OS cells and HCT116 cells with lowdose Nex (up to $5 \mu \mathrm{g} / \mathrm{ml}$ ), no clear apoptosis was observed (data not shown). Considering that $1 \mu \mathrm{g} / \mathrm{ml} \mathrm{Nex}$ is able to efficiently inhibit cell growth, we hypothesize that Nex has one or more mechanisms in addition to apoptosis induction to prevent cancer cell growth.

Based on this hypothesis, we explored the potential causes of media acidification after Nex treatment and found that Nex was able to enhance lactate production in U2OS and HeLa cells without altering LDH activity. LDH is a key regulator of whether pyruvate enters the tricarboxylic acid cycle (TAC) or is eliminated from cells as lactate [31]. Because no change in LDH activity after Nex treatment was observed, Nex might block pyruvate consumption and enhance lactate production. We also examined mitochondria, where it was observed that Nex damaged mitochondria in a dose-dependent manner. Considering that mitochondria play a key role in the apoptosis/autophagy balance, we further examined autophagy status in Nex- 


\section{Cellular Physiology Cell Physiol Biochem 2015;36:763-772 \\ \begin{tabular}{l|l} 
and Biochem $10.1159 / 000430136$ & $\begin{array}{l}\text { C } 2015 \mathrm{~S} \text {. Karger AG, Basel } \\
\text { www.karger.com/cpb }\end{array}$ \\
\cline { 2 - 3 }
\end{tabular} \\ Wu et al:: Nexrutine Inhibits Cancer Cell Growth Through an Autophagy-dependent Mechanism}

treated U2OS and HeLa cells (data not shown). In Nex-treated cells, GFP-LC3 accumulated and aggregated with damaged mitochondria, indicating that autophagy had been activated. To date, all previous studies of Nex focused on its apoptotic function at relatively higher doses with relatively shorter treatment times than the current study [29, 30, 32-34]. As a nutrient supplement, Nex (normally $250 \mathrm{mg}$ /day) takes effect at a much lower concentration than the experimental doses used for short-term treatments. Thus, we treated cells with a relatively low dose of Nex for a week. No clear apoptosis was observed in U2OS, HeLa or HCT116 cells, but significant autophagy and cell growth inhibition were observed. Most cancer cells developed multiple strategies to inactivate apoptosis pathways [35]. Compared with apoptosis, activation of autophagy is considered effective for treating cancer because autophagy is relatively intact in cancer cells. Thus, Nex has potential applications in cancer prevention and cancer therapy as an autophagy activator.

Our data suggest that the cell growth inhibition effect of Nex is autophagy-dependent but not p53-dependent. p53 is considered the most important regulator of p21 because two important p53 binding sites exist on the p21 promoter [36]. Cancer cells with mutated p53 and cancer cells lacking p53 cannot efficiently respond to various stimulations, including irradiation and chemotherapy [37, 38]. Nex treatment decreases osteosarcoma and colon cancer cell proliferation rates in a p53-independent manner. This p53-independent induction of $\mathrm{p} 21$ expression by Nex is meaningful for the prevention and treatment of cancer, as the loss or mutation of p53 is one of the most commonly observed changes that occur in human cells that develop into cancers. BCL2 is frequently overexpressed in cancer cells and protects them from multiple types of treatments $[39,40]$. Cell growth inhibition by Nex is independent of BCL2, which is meaningful for cancer prevention and therapy.

Mito-Tracker is used to probe for mitochondrial damage, and different types of MitoTracker have different cell type specificities. Dr. Reynolds' group reported that three types of Mito-Tracker, including orange, green and red, are applicable in neurons and astrocytes [41]. Based on our observations, the fluorescence change of Mito-Tracker red was well-correlated with mitochondrial damage in U2OS and HeLa cells.

The major type of autophagy caused by Nex is mitophagy, as indicated by LC3 being primarily localized with damaged mitochondria. It is unclear how Nex induces mitochondrial damage and whether COX-2, AKT or CREB participates in this process, and understanding the mechanism of the mitochondrial damage effect of Nex is an important next step for studies of Nex.

\section{Disclosure Statement}

The authors declare no conflicts of interest.

\section{Acknowledgements}

This work was supported by a grant from Hunan Provincial Health Department research funds (B2010-082) ) and National Natural Science Foundation of China (81201240).

\section{References}

1 Seaver B, Smith JR: Inhibition of COX isoforms by nutraceuticals. J Herb Pharmacother 2004;4:11-18.

2 Ghosh R, Garcia GE, Crosby K, Inoue H, Thompson IM, Troyer DA, Kumar AP: Regulation of Cox-2 by cyclic AMP response element binding protein in prostate cancer: potential role for nexrutine. Neoplasia 2007;9:893-899. 


\section{Cellular Physiology Cell Physiol Biochem 2015;36:763-772 \begin{tabular}{ll|l} 
and Biochemistry & $\begin{array}{l}\text { DOI: 10.1159/000430136 } \\
\text { Published online: May 22, } 2015\end{array}$ & $\begin{array}{l}\text { (c) 2015 S. Karger AG, Basel } \\
\text { www.karger.com/cpb }\end{array}$ \\
\cline { 2 - 2 }
\end{tabular} \\ Wu et al: Nexrutine Inhibits Cancer Cell Growth Through an Autophagy-dependent
Mechanism}

3 Yount G, Qian Y, Moore D, Basila D, West J, Aldape K, Arvold N, Shalev N, Haas-Kogan D: Berberine sensitizes human glioma cells, but not normal glial cells, to ionizing radiation in vitro. J Exp Ther Oncol 2004; 4:137-143.

4 Hou Q, Tang X, Liu H, Tang J, Yang Y, Jing X, Xiao Q, Wang W, Gou X, Wang Z: Berberine induces cell death in human hepatoma cells in vitro by downregulating CD147. Cancer Sci 2011;102:1287-1292.

5 Liu B, Wang G, Yang J, Pan X, Yang Z, Zang L: Berberine inhibits human hepatoma cell invasion without cytotoxicity in healthy hepatocytes. PLoS One 2011;6:e21416.

6 Garcia GE, Nicole A, Bhaskaran S, Gupta A, Kyprianou N, Kumar AP: Akt-and CREB-mediated prostate cancer cell proliferation inhibition by Nexrutine, a Phellodendron amurense extract. Neoplasia 2006;8:523-533.

7 Nohl H, Gille L, Staniek K: Intracellular generation of reactive oxygen species by mitochondria. Biochem Pharmacol 2005;69:719-723.

8 Green DR, Galluzzi L, Kroemer G: Mitochondria and the autophagy-inflammation-cell death axis in organismal aging. Science 2011;333:1109-1112.

9 Luanpitpong S, Chanvorachote P, Nimmannit U, Leonard SS, Stehlik C, Wang L, Rojanasakul Y: Mitochondrial superoxide mediates doxorubicin-induced keratinocyte apoptosis through oxidative modification of ERK and Bcl-2 ubiquitination. Biochem Pharmacol 2012;83:1643-1654.

10 Das A, Gopalakrishnan B, Voss OH, Doseff AI, Villamena FA: Inhibition of ROS-induced apoptosis in endothelial cells by nitrone spin traps via induction of phase II enzymes and suppression of mitochondriadependent pro-apoptotic signaling. Biochem Pharmacol 2012;84:486-497.

11 Sinha K, Das J, Pal PB, Sil PC: Oxidative stress: the mitochondria-dependent and mitochondria-independent pathways of apoptosis. Arch Toxicol 2013;87:1157-1180.

12 Shi JM, Bai LL, Zhang DM, Yiu A, Yin ZQ, Han WL, Liu JS, Li Y, Fu DY, Ye WC: Saxifragifolin D induces the interplay between apoptosis and autophagy in breast cancer cells through ROS-dependent endoplasmic reticulum stress. Biochem Pharmacol 2013;85:913-926.

13 Caputo F, Vegliante R, Ghibelli L: Redox modulation of the DNA damage response. Biochem Pharmacol 2012;84:1292-1306.

14 Lizama-Manibusan B, McLaughlin B: Redox modification of proteins as essential mediators of CNS autophagy and mitophagy. FEBS Lett 2013;587:2291-2298.

15 Choi AM, Ryter SW, Levine B: Autophagy in human health and disease. N Engl J Med 2013;368:651-662.

16 Terman A, Brunk UT: Lipofuscin: mechanisms of formation and increase with age. APMIS 1998;106:265276.

17 Lemasters JJ: Selective mitochondrial autophagy, or mitophagy, as a targeted defense against oxidative stress, mitochondrial dysfunction, and aging. Rejuvenation Res 2005;8:3-5.

18 Peng X, Li W, Yuan L, Mehta RG, Kopelovich L, McCormick DL: Inhibition of proliferation and induction of autophagy by atorvastatin in PC3 prostate cancer cells correlate with downregulation of Bcl2 and upregulation of miR-182 and p21. PLoS One 2013;8:e70442.

19 Qi M, Zhou H, Fan S, Li Z, Yao G, Tashiro S, Onodera S, Xia M, Ikejima T: mTOR inactivation by ROS-JNK-p53 pathway plays an essential role in Psedolaric acid B induced autophagy-dependent senescence in murine fibrosarcoma L929 cells. Eur J Pharmacol 2013;715:76-88.

20 Cho YY, Kim DJ, Lee HS, Jeong CH, Cho EJ, Kim MO, Byun S, Lee KY, Yao K, Carper A, Langfald A, Bode AM, Dong Z: Autophagy and cellular senescence mediated by Sox2 suppress malignancy of cancer cells. PLoS One 2013;8:e57172.

21 Arndt CA, Crist WM: Common musculoskeletal tumors of childhood and adolescence. N Engl J Med 1999;341:342-352.

22 Cortes EP, Holland JF, Wang JJ, Sinks LF, Blom J, Senn H, Bank A, Glidewell 0: Amputation and adriamycin in primary osteosarcoma. N Engl J Med 1974;291:998-1000.

23 Ochs JJ, Freeman AI, Douglass HO, Jr., Higby DS, Mindell ER, Sinks LF: cis-Dichlorodiammineplatinum (II) in advanced osteogenic sarcoma. Cancer Treat Rep 1978;62:239-245.

24 Jaffe N, Paed D, Farber S, Traggis D, Geiser C, Kim BS, Das L, Frauenberger G, Djerassi I, Cassady JR: Favorable response of metastatic osteogenic sarcoma to pulse high-dose methotrexate with citrovorum rescue and radiation therapy. Cancer 1973;31:1367-1373. 


\section{Cellular Physiology Cell Physiol Biochem 2015;36:763-772 \\ \begin{tabular}{ll|l} 
and Biochemistry & $\begin{array}{l}\text { DOI: 10.1159/000430136 } \\
\text { Published online: May 22, } 2015\end{array}$ & $\begin{array}{l}\text { ( ) 2015 S. Karger AG, Basel } \\
\text { www.karger.com/cpb }\end{array}$ \\
\cline { 2 - 3 }
\end{tabular} \\ Wu et al.: Nexrutine Inhibits Cancer Cell Growth Through an Autophagy-dependent Mechanism}

25 Harris MB, Cantor AB, Goorin AM, Shochat SJ, Ayala AG, Ferguson WS, Holbrook T, Link MP: Treatment of osteosarcoma with ifosfamide: comparison of response in pediatric patients with recurrent disease versus patients previously untreated: a Pediatric Oncology Group study. Med Pediatr Oncol 1995;24:87-92.

26 Miura M, Zhu H, Rotello R, Hartwieg EA, Yuan J: Induction of apoptosis in fibroblasts by IL-1 betaconverting enzyme, a mammalian homolog of the C. elegans cell death gene ced-3. Cell 1993;75:653-660.

27 Koppenol WH, Bounds PL, Dang CV: Otto Warburg's contributions to current concepts of cancer metabolism. Nat Rev Cancer 2011;11:325-337.

28 Vander Heiden MG: Targeting cancer metabolism: a therapeutic window opens. Nat Rev Drug Discov 2011;10:671-684.

29 Kumar R, Das M, Ansari KM: Nexrutine(R) inhibits tumorigenesis in mouse skin and induces apoptotic cell death in human squamous carcinoma A431 and human melanoma A375 cells. Carcinogenesis 2012;33:1909-1918.

30 Yan G, Lanza-Jacoby S, Wang C: Nexrutine Inhibits Survival and Induces G1 Cell Cycle Arrest, Which Is Associated with Apoptosis or Autophagy Depending on the Breast Cancer Cell Line. Nutr Cancer 2014;66:506-516.

31 Draoui N, Feron 0: Lactate shuttles at a glance: from physiological paradigms to anti-cancer treatments. Dis Model Mech 2011;4:727-732.

32 Kumar AP, Graham H, Robson C, Thompson IM, Ghosh R: Natural products: potential for developing Phellodendron amurense bark extract for prostate cancer management. Mini Rev Med Chem 2010;10:388397.

33 Kumar AP, Bhaskaran S, Ganapathy M, Crosby K, Davis MD, Kochunov P, Schoolfield J, Yeh IT, Troyer DA, Ghosh R: Akt/cAMP-responsive element binding protein/cyclin D1 network: a novel target for prostate cancer inhibition in transgenic adenocarcinoma of mouse prostate model mediated by Nexrutine, a Phellodendron amurense bark extract. Clin Cancer Res 2007;13:2784-2794.

34 Ghosh R, Graham H, Rivas P, Tan XJ, Crosby K, Bhaskaran S, Schoolfield J, Banu J, Fernandes G, Yeh IT, Kumar AP: Phellodendron amurense bark extract prevents progression of prostate tumors in transgenic adenocarcinoma of mouse prostate: potential for prostate cancer management. Anticancer Res 2010;30:857-865.

35 Malhi H, Gores GJ, Lemasters JJ: Apoptosis and necrosis in the liver: a tale of two deaths? Hepatology 2006;43:S31-44.

36 el-Deiry WS, Tokino T, Velculescu VE, Levy DB, Parsons R, Trent JM, Lin D, Mercer WE, Kinzler KW, Vogelstein B: WAF1, a potential mediator of p53 tumor suppression. Cell 1993;75:817-825.

37 Strigari L, Mancuso M, Ubertini V, Soriani A, Giardullo P, Benassi M, D'Alessio D, Leonardi S, Soddu S, Bossi G: Abscopal effect of Radiation therapy: Interplay between radiation dose and p53 Status. Int J Radiat Biol 2014;90:248-255.

38 Saha MN, Qiu L, Chang H: Targeting p53 by small molecules in hematological malignancies. J Hematol Oncol 2013;6:23.

39 Lam LT, Zhang H, Chyla B: Biomarkers of therapeutic response to BCL2 antagonists in cancer. Mol Diagn Ther 2012;16:347-356.

40 Di Cresce C, Koropatnick J: Antisense treatment in human prostate cancer and melanoma. Curr Cancer Drug Targets 2010;10:555-565.

41 Buckman JF, Hernández H, Kress GJ, Votyakova TV, Pal S, Reynolds IJ: Mito-Tracker labeling in primary neuronal and astrocytic cultures: influence of mitochondrial membrane potential and oxidants. J Neurosci Meth 2001;104:165-176. 